\title{
A multidisciplinary monitory centre by smallholders in Cameroon to identify factors limiting plantain production
}

\author{
Emmanuel Desdoigts*, Moïse Kwa, Roger Fogain, Ludovic Temple, Patrick Sama Lang, Achille Bıkoï, Raphaël AchaRd
}

CARBAP (Centre Africain de Recherche sur les Bananiers et Plantains), BP 832, Douala, Cameroon

edesdoigts@hotmail.com crbp@camnet.cm

${ }^{*}$ Correspondence and reprints

Fruits, 2005, vol. 60, p. 237-244 (C) 2005 Cirad/EDP Sciences All rights reserved

DOI: $10.1051 /$ fruits:2005030

RESUMEN EsPAÑOL, p. 244

\section{A multidisciplinary monitory centre by smallholders in Cameroon to identify factors limiting plantain production.}

Abstract - Introduction. In Cameroon, plantain plays a major role in food security. An increase in production is necessary to satisfy the demand. Since April 2002, CARBAP has supported a monitory centre of plantain production. The main objective is to prioritise studies of production constraints and characterise commercialisation strategies, in order to improve profitability for smallscale farmers. Materials and methods. Eighteen plots were identified within farms that represent the agro-ecological and socio-economic diversity of the region. Plots were considered as the sampling unit for agronomic and pathogenic constraints analysis. Farms were considered as the sampling unit used in the socio-economic constraint analysis. For each plot, a regular survey of 50 banana plants and agronomic practices was carried out. A survey of each farm was also set for the observation of production conditions thanks to the participation of smallholders. Results. It is possible to distinguish smallholders with different levels of diversification towards plantain production. Agronomic results in the plots surveyed were judged thanks to parameters of growth, yield and pest infestation. Good/bad results on young/older plots were basically distinguished. These divisions of individuals are influenced by initial factors (varieties available for planting, former crops in the plot), means available (inputs) and technical skills in plantain cultivation. Conclusion. This method allows the detection of indicators of diversification towards plantain cultivation and allows one to check the sustainability of such strategies. It is possible to propose improved technical practices. They will be used for further local studies aimed at improving the plantain production.

Cameroon / Musa (plantains) / surveying / economic analysis / yield components / fungal diseases / parasitism

\section{Un observatoire multidisciplinaire auprès de petits exploitants au Cameroun pour identifier les facteurs limitant la production de plantain.}

Résumé - Introduction. Au Cameroun, le plantain joue un rôle important pour la sécurité alimentaire. Une augmentation de la production serait nécessaire pour satisfaire la demande. Depuis avril 2002, le CARBAP maintient un observatoire de la production de plantain. L'objectif principal est d'étudier en priorité les contraintes de production et de caractériser les stratégies de commercialisation, afin d'améliorer la rentabilité de cette culture pour les petits exploitants. Matériel et méthodes. Dix-huit parcelles de terrain ont été identifiées dans des fermes représentatives de la diversité agro-écologique et socio-économique de la région. Ces parcelles ont été considérées comme unité d'échantillonnage pour l'analyse agronomique et celle des contraintes parasitaires. Les fermes ont été considérées comme unité élémentaire utilisée pour l'analyse des contraintes socio-économiques. Pour chaque parcelle, un suivi régulier de 50 plants de banane et des pratiques agronomiques a été effectué. Grâce à la participation des petits exploitants, un suivi de chaque ferme a été également mis en place pour l'analyse des conditions de production. Résultats. Il est possible de distinguer les petits exploitants à partir de différents niveaux de diversification des cultures par rapport à la production de plantain. Les résultats agronomiques dans les parcelles examinées ont été évalués grâce aux paramètres de croissance, de rendement et d'infestation parasitaire. Les bons ou mauvais résultats sur jeunes ou vieilles parcelles ont été fondamentalement identifiés. Les différences individuelles sont influencées par des facteurs de départ (variétés disponibles lors de la plantation, culture antérieure sus la parcelle), les moyens disponibles (intrants) et les capacités techniques pour la culture du plantain. Conclusion. Le dispositif mis en place permet de détecter des indicateurs de diversification vis-à-vis de la culture de plantain et de vérifier la durabilité de telles stratégies. Il est possible de proposer des techniques de culture améliorées. Elles pourront être utilisées au cours d'études à venir visant l'amélioration de la production de plantain.

Cameroun / Musa (plantains) / relevé (des données) / analyse économique / composante de rendement / maladie fongique / parasitisme 


\section{Introduction}

In Cameroon, plantain plays a major role in food security. An increase in production is necessary to satisfy the demand.

In order to orientate research issues on plantain production and properly define development projects in the region under investigation, it appeared necessary to determine the production-limiting factors and flow of plantain.

In order to collect data useful for accessing this information, a monitory centre consisting of a multidisciplinary method for surveying smallholder plots had been installed since April 2002 by the Centre Africain de Recherche sur les Bananiers et Plantains (CARBAP). The main limiting factors then studied were those related to the environmental and social-economic conditions of production, the agronomic practices and the influence of pathogens on this production [1]

In the region to be studied, farms that show the diversity of existing situations both at the agro-ecological and socio-economic levels were identified. This identification was based on former general skills relative to climate, topography, soil types and socioeconomic profiles of smallholders. Fieldwork was led aiming at finding farms representative of the entire diversity of the region investigated. In the case of the monitory centre conducted in Cameroon, 18 farms were chosen.

Inside each identified farm, the plot that best fitted with future observations was chosen. General rules to make such a choice were based on the size of plots and considerations about crop associations (monocropped plantations, mixed cultivations with food / cash crops).

For each plot, a monthly survey of banana plants and agronomic practices was carried out. A monthly survey of each farm was also set for the observation of production conditions (labour, economic results, etc.).

Data collected in a database bringing together all the parameters observed were analysed. The fieldwork involved the participation of smallholders to ensure a good record of economic and harvesting data.
The analysis of the collected data integrated the different levels of the crop (plant, plot and farm) and its key parameters (agro-ecological and socio-economic). The diagnosis of smallholder strategies was carried out in the framework of their production system. The method was flexible enough to take into account changes linked to necessary replacement of banana plants and plots or even a change in smallholders during the ongoing study.

\section{Choice of plants observed and materials}

\subsection{Identification of the region}

The monitory centre comes within the scope of research issues and objectives of development previously planned. The choice of the region was therefore the first stage to ensure that the results obtained could satisfy these requirements.

In the case of the method set up in Cameroon, objectives of sedentarisation of agroforestry with the development of sustainable production systems for the improvement of local food security led researchers to choose the region supplying Douala (the biggest town of Cameroon) with plantain. This region is a $100-\mathrm{km}$ stretch from north to south. This choice was justified (i) by the impact of the supposed results to be obtained which would satisfy the objectives cited above and (ii) by the presence of infrastructures, and human and material means available within this region.

\subsection{Identification of the farms}

Farms were defined as means (land, labour and capital) gathered by a smallholder and his family to reach goals (chosen by them). This definition includes considerations about strategies carried out to reach this goal. Farms where plantain plays an important role were identified. Besides these criteria, choice of the farms also included identification of the potential plots for observation. 
In order to identify farms, the support of the local authorities and the agricultural extension staff, who know the farmers of their areas well, was helpful. Direct observations of plots in the areas investigated were another possibility to identify potential farms for the study. Another approach consisted of undertaking inquiries in production markets to select smallholders producing plantain for commercial purpose. A diversity of socio-economic profiles was sought (pluriactivity, cash / food crops as main source of income) as well as the identification of different crop associations in plots targeted for the upcoming survey. One last condition for identifying farms was to check the motivation of the smallholder to work with a research team for several years. While subjective, attention must be paid to this criterion.

\subsection{Identification of the plots}

Plots were defined as portions of land cultivated with a single crop or a crop mixture (for at least one agricultural season). Besides considerations of crop associations, a range of 100 banana plants had to be planted in each plot for further selection, 50 of them having to be selected for observations, as explained below.

\subsection{Identification of the plants}

For each plot observed, 50 banana plants per plot were chosen based on the following criteria:

- Banana plants presented a homogeneous distribution within the plot.

- Banana plants were chosen at an early vegetative stage (first or second cycle to follow the whole development of the banana plants through several cycles).

- A plot with a single cultivar had to be selected: this is quite easy in large plots where most of the banana plants belong to one or two varieties, but this is more difficult in home gardens where diversity is higher. It was preferable to choose plots with the same cultivar. Experience showed that this is generally possible even in a large area where all the banana plants were repre- sented by a small number of cultivars widely spread.

- Identification of plots with plants at the same cycles of development (first or second crop cycle) was recommended to follow them for 3 years.

- Banana plants were numbered and marked out thanks to a ribbon knotted around the pseudostem. Among the 50 banana plants chosen inside each plot, 10 were selected for additional biological and physico-chemical observations (nematology, entomology, leaf analysis and soil analysis).

\subsection{Time required}

The time required to collect data is between $1.5 \mathrm{~h}$ and $2 \mathrm{~h}$ for four people per smallholder. Experience showed that four to five smallholders could be visited each day, corresponding to 20 to 25 per week. Two people are required to collect agronomic parameters and one more to collect entomological and nematological parameters. A fourth person collects economic data and helps the first ones to achieve fieldwork. This last person generally manages the group of observers. An increase in the number of smallholders surveyed led to either creating additional work teams or decreasing the size of the region investigated.

Furthermore, each farmer must take a few minutes each day to fill in forms.

The monitory centre of production set up to collect data should last for at least 1 year, preferably 3 years, to give a good representation of the situation.

\subsection{Materials}

The materials necessary for the smallholders surveyed are pens, forms to record economic and harvest parameters and scales to weigh harvested bunches.

The work team needs transport facilities, forms to record agronomic, entomological and nematological parameters, a computer, a tape measure, a cutlass, a "coffee digger" for soil samples, a sampling bag for root samples, a centrifugation device and a microscope for nematology analysis. 


\section{Protocol}

\subsection{Parameters observed on banana plants}

Growth and development parameters are registered on bananas of each plot every 4 weeks. They are: cycle number of the banana plant; circumference of the pseudostem (at $10 \mathrm{~cm}$ from the ground); total number of leaves; number of leaves alive; date of the eventual loss of the bunch (or of the banana plant during the vegetative phase); kind of loss for the bunch or banana plant (fall, disease, theft, etc.); stage of loss (vegetative, flowering or harvesting); date of flowering; banana plant height at flowering; number of suckers at flowering. Leaf samplings are made once after flowering on the 10 banana plants chosen for that purpose. The chemical composition of samples is analysed.

For each harvested bunch, data are collected regarding the date of bunch harvest, the bunch weight, the number of hands per bunch, the number of fingers per hand and the price of sale. Concerning this last parameter, bunches are often sold in groups and the price is therefore a mean price. Thus, the price of sale can be recorded only if the bunch is sold alone or if the price of each bunch inside the group has been discussed separately.

A harvested bunch is not stored but preferably sold or consumed within one day. As the work team visits each farm only once a month, these bunches often cannot be observed directly. For that reason, these observations must be made by the smallholders.

Weevil impact is assessed by installing traps every 8 weeks. These traps constitute half sections of pseudostems from the base of 10 banana plants chosen for that purpose. Weevils (Cosmopolites sordidus, Metamasius spp. and Pollytus spp.) are then identified and counted 10 days after setting up the traps. Moreover, when the bunches are harvested (or when the banana plant is lost before being harvested), the bulb is decorticated to control the infestation coefficient according to Vilardebo's method [2], which must be assessed 10 days maximum after harvest (or banana plant loss).
To assess the nematology impact:

- Root samples are collected on 10 banana plants chosen for that purpose and the fragments are conserved in a single plastic bag. Then, 10 fragments $10 \mathrm{~cm}$ long are taken at random from this bag and cut lengthways. The necrosis length is measured on each side ( $a$ and $b$ ) of the central cylinder of each $10-\mathrm{cm}-$ long root fragment. The ratio $[(\mathrm{a}+\mathrm{b}) /$ 10] gives the root necrosis index for the fragment; then, the necrosis root index of the plot is calculated by the mean ratio for the 10 fragments studied.

- To identify and count the nematode species, samples collected in the field are washed with distilled water, cut into small pieces (1-2 cm long) and mixed with distilled water. An aliquot of $20 \mathrm{~g}$ of this mixture is smashed and centrifuged to obtain $100 \mathrm{~mL}$ of nematode suspension. Three 1-mL samples (L1, L2 and L3) are used for observation under a microscope. Nematodes (Radopholus similis, Meloidogyne spp., Hoplolaimus spp., Pratylenchus goodey and Helicotylenchus spp.) are then identified and counted and the quantity of nematodes of each species for $100 \mathrm{~g}$ of roots is calculated.

\subsection{Soil parameters in each plot}

To study the soil profile physical characteristics, one to three soil profiles are selected according to the homogeneity of the soil plot (soil depth, colour and texture, etc.). The exact position of the profile inside the plot is noted, and the soil depth, soil pH and root depth of banana plants are determined.

For each horizon in each profile, the depth of each horizon, horizon colour (according to the Munsell chart), horizon texture (clay / silt / sand proportions) according to the FAO texture triangle, horizon structure, quantity of gravel, stone and rock proportion (IPGRI-INIBAP) and soil porosity (percentage of air compared with total volume) are observed. Soil moisture is controlled once during the dry season and once during the rainy season at two different depths (10 cm deep and $20 \mathrm{~cm}$ deep) and at least $1 \mathrm{~m}$ away from the banana plants. According to the heterogeneity of the plot, more than one observation can be necessary. 
Table I.

Agronomic and economic parameters registered by plantain smallholders filling in forms used to identify production-limiting factors to take into account, with the target of improving the profitability of their crops. Each category of activity presented in the columns is the subject of a grid that the smallholders have to fill in every day from the parameters listed. Thus, six different grids are available.

\begin{tabular}{|c|c|c|c|c|c|}
\hline $\begin{array}{l}\text { Purchases } \\
\text { for the surveyed plot }\end{array}$ & $\begin{array}{l}\text { Harvesting } \\
\text { of plantain }\end{array}$ & $\begin{array}{l}\text { Sales for other } \\
\text { crops than plantain }\end{array}$ & $\begin{array}{l}\text { Work carried out } \\
\text { in the surveyed plot }\end{array}$ & $\begin{array}{l}\text { Expenses in labour } \\
\text { for other crops } \\
\text { than plantain }\end{array}$ & $\begin{array}{c}\text { Other activities } \\
\text { which yielded money }\end{array}$ \\
\hline Crop concerned & Harvest date & Crop concerned & Date of the work & Crop concerned & Date of activity \\
\hline Date of the purchase & $\begin{array}{c}\text { Number of bunches } \\
\text { harvested }\end{array}$ & Plot concerned & Work type & Expense date & Type of activity \\
\hline Material purchased & $\begin{array}{l}\text { Number of bunches } \\
\text { sold }\end{array}$ & Date of sale & $\begin{array}{l}\text { If remunerated workers: } \\
\text { - number of workers, } \\
\text { - time of labour/worker (h), } \\
\text { - total time of labour (T1), } \\
\text { - expenses of labour }\end{array}$ & Work carried out & $\begin{array}{c}\text { Type of expenses } \\
\text { For this activity } \\
\text { (labour, purchase, etc.) }\end{array}$ \\
\hline Unit price & Place of selling & Place of sale & $\begin{array}{l}\text { If unpaid workers: } \\
\text { - number of unpaid workers } \\
\text { - time of labour/worker (h), } \\
\text { - total time of labour (T2) }\end{array}$ & $\begin{array}{l}\text { Number of } \\
\text { workers }\end{array}$ & $\begin{array}{l}\text { Costs of these } \\
\text { expenses } \\
\text { for this activity }\end{array}$ \\
\hline Quantity & Money earned & Quantity sold & $\begin{array}{l}\text { Total time of labour }(T 1+T 2) \\
\text { for remunerated } \\
\text { and unpaid workers }(h)\end{array}$ & Money spent & $\begin{array}{l}\text { Money earned } \\
\text { with this activity }\end{array}$ \\
\hline Total cost & - & Unit price & - & - & - \\
\hline- & - & Money earned & - & - & - \\
\hline
\end{tabular}

For the soil physico-chemical characteristic analysis, two samples of soil are taken at the level of the 10 banana plants selected: the first one at $10 \mathrm{~cm}$ deep and the second below $20 \mathrm{~cm}$ deep. Granulometry is determined, and the $[\mathrm{C} / \mathrm{N}]$ ratio, phosphorus content (use of Olsen's or Bray-2's methods) and potassium, calcium and magnesium contents are calculated.

\subsection{Agronomic practices and economic parameter survey}

Agronomic and economic information is registered by the smallholders, provided with forms to fill in every day (table I). The data below were noted:

- Date, type (plant material, suckers, fertilisers, pesticides, material) and place of purchase, quantity, unit, unit price, total cost, etc. for the surveyed plot and for all the other plots.
- Harvesting of plantain in the surveyed plot and data regarding the sale: date, number of bunches harvested, number of bunches sold, place of selling, money earned. Note that this included the 50 banana plants observed in the plots, as well as the other ones in this plot.

- Sales on all other plots (date of sale, place, quantity sold, unit, money earned).

- Work carried out in the surveyed plot: date, type of work, number of remunerated workers, time of their labour in hours, expenses in labour, number of unpaid workers (generally the smallholder himself and his family), time of their labour in hours.

- Expenses in labour on all the other plots: date, work carried out, number of workers, money spent.

- Other activities including animal sales, timber sawing, joinery, weaving of roof mat, etc.: date, type of activity, type of expenses for this activity, costs of these expenses for this activity, money earned with this activity. 
This survey by the smallholders is done through a participatory approach:

- Data from the smallholders collected every 4 weeks.

- Previous data completed by questions to the smallholders concerning the borrowing and lending done by the smallholder (date, reason, amount, interest rate, date of repayment).

\subsection{Data analysis}

After the fieldwork, all data are recorded in a database.

Typologies of farms are identified through a statistical approach (Principal Component Analysis or PCA); for this analysis, the main parameters to take into account included those related to the cultivation system and to the economic results obtained. The PCA shows strategies adopted by each smallholder (importance of cash crops, food crops, plantain sales, levels of investment, type of work, etc.).

Evolution of the farm through the analysis of agronomic and harvest parameters observed during several years are identified. The leaf emission rhythm and time between flowering and harvest are calculated. The impact of entomological, nematological and soil parameters are identified through an analysis of the difference between plots or through variation within the same plot. These parameters are partly explained by agronomic practices, recorded by smallholders.

Finally, the sustainability of the different strategies of the smallholders (shown thanks to the typologies carried out) are checked through the evolution of plots (fertility, pests, crops, etc.) and harvest results.

\section{Results}

The expected results concern the identification of (i) major constraints of production, taking into account the diversity of situations and (ii) potential assessment for the development of plantain cultivation and marketing in the region investigated through a participatory approach.
Former results [3] showed that, under smallholder conditions, losses of banana plants before harvest often surpass 30\% of total banana plants initially planted. To get correct figures concerning yields, a sufficient number of bunches must be observed (20 to 30) and, consequently, other banana plants of the same variety, cycle and development stages must replace the ones lost. This is of particular importance when the global number of banana plants is decreasing with time.

A "feedback" of information should be planned to maintain the participatory approach with smallholders (especially recording of data). For instance, a balance sheet can be given each month, showing total receipts and expenses with a few indicators such as the mean price of bunches sold or average daily salary of people employed, etc. Experience shows this is an efficient way to make smallholders interested in the method.

It is noted that this method does not allow the surveying of a large number of smallholders. Therefore, typical results mostly concern plot evolution dynamics and smallholder typologies. Generalisation to other regions than the one investigated should be done cautiously and it would be preferable to set up similar devices for other regions. In that case, the different work teams should meet regularly to gather results for further comparisons.

\section{Discussion}

The monitory centre currently operating in Cameroon aims to (i) validate the methodology used between 1997 and 2001 for observation of plantain production under smallholder conditions, (ii) classify plantain production and marketing constraints to sort out research priorities and (iii) create partnerships through detection of local potential and projects so as to develop the plantain production.

\subsection{Validation of the methodology used between 1997 and 2001}

Our methodology is multidisciplinary and participative. The different scales of investigation 
(plant, plot and farm) allow a global understanding of plantain cultivation and its role inside production strategies. The efficiency of this method is working correctly to record, store and analyse data. Nevertheless, in the long term, this efficiency decreases (plots abandoned, farmers non-motivated). The improvements proposed above should allow the creation of more efficient and less expensive devices, producing results more quickly.

\subsection{Sorting out research priorities}

Concerning plantain production and marketing constraints, our method gives interesting results by adding to former ones. We confirm the black weevil as an important constraint. Certain variables used as yield indicators are called into question, number of fingers of the bunch, for instance. Certain parameters can explain this situation. However, it is necessary to complement date series to be able to give stronger conclusions.

\subsection{Developing the plantain production}

This objective is partly reached. Our method allowed us do detect farmers or groups of farmers diversifying towards plantain production and marketing. However, only one project has started and concerns a farmer with strong investment means. CARBAP cannot manage all demands because of its own objectives of research. In the framework of this monitory centre, more partnerships should be set up with governmental institutions and GNOs to satisfy the demands of farmers to develop plantain production.

\section{Conclusions}

The monitory centre of plantain production set up in April 2002 gives encouraging results, which are still being completed now. The data collected will allow us to see the evolution of strategies and yields. Sustainable strategies should be widely transferred thanks to governmental institutions and GNOs.

Finally, other monitory centres to be set up in Cameroon and other African regions should articulate around a single global objective, which is the development of plantain production and marketing inside regions with the best agro-economic potential. This supposes to investigate local production markets, to make samples and to develop participative approaches (economic data, yields) to obtain results more quickly.

\section{References}

[1] Iratchet B., Un outil pour orienter la recherche et apporter des réponses aux problèmes des producteurs de plantains dans le sud-ouest du Cameroun: l'exemple de l'observatoire agro-phytosanitaire, in: Boto I., Fouré E., Ngalani J., Thornton T., Valat M. (Éds.), Les productions bananières: un enjeu économique majeur pour la sécurité alimentaire, Symposium, novembre 1998, Douala, Cameroun, Cirad, Montpellier, France, 1998, pp. 21-22.

[2] Vilardebo A., Le coefficient d'infestation, critère d'évaluation du degré d'attaques des bananeraies par Cosmopolites sordidus Germ., le charançon noir du bananier, Fruits 18 (3) (1973) 251-260.

[3] Pierrot J., Achard R., Temple L., Abadie C., Fogain R., Déterminants de la production de plantain dans le sud-ouest du Cameroun: intérêt d'un observatoire, Fruits 57 (2) (2002) 75-85. 


\section{Un observatorio multidisciplinar dirigido a pequeños explotadores en Camerún para definir los factores que limitan la producción de plátanos.}

Resumen - Introducción. En Camerún, el plátano desempeña un papel importante para la seguridad alimenticia. Sería necesario un aumento de la producción para satisfacer la demanda. Desde abril 2002, el Carbap mantiene un observatorio de la producción de plátano. El objetivo principal consiste en estudiar prioritariamente las dificultades de producción y en caracterizar las estrategias de comercialización, con el fin de mejorar la rentabilidad de esta cultura para los pequeños explotadores. Material y métodos. Se identificaron dieciocho parcelas de terreno en explotaciones representativas de la diversidad agro-ecológica y socioeconómica de la región. Estas parcelas se consideraron como unidad de muestreo para el análisis agronómico y para el análisis de las dificultades parasitarias. Las explotaciones se consideraron como unidad básica utilizada para el análisis de las dificultades socioeconómicas. Para cada parcela, se efectuó un seguimiento regular de 50 plantas de plátano y de prácticas agronómicas. Gracias a la participación de los pequeños explotadores, también se realizó un seguimiento de cada explotación para el análisis de las condiciones de producción. Resultados. Es posible distinguir los pequeños explotadores a partir de distintos niveles de diversificación de las culturas con relación a la producción de plátano. Los resultados agronómicos de las parcelas examinadas se evaluaron mediante los parámetros de crecimiento, rendimiento y de infestación parasitaria. Se identificaron básicamente los resultados buenos y malos en parcelas jóvenes o viejas. Las diferencias individuales se influyen en factores iniciales (variedades disponibles en el momento de la plantación, el cultivo anterior en esa parcela), por los medios disponibles (entradas) y en las capacidades técnicas para la cultura del plátano. Conclusión. El dispositivo establecido permite, por un lado, detectar indicadores de diversificación en referencia a la cultura del plátano; Y, por el otro, comprobar la duración de tales estrategias. Es posible proponer técnicas de cultivo mejoradas. Podrán utilizarse en el curso de futuros estudios destinados a la mejora de la producción de plátanos.

Camerún / Musa (platanos) / procedimiento de la encuesta / análisis económico / caracteres de rendimiento / enfermedades fungosas / parasitismo

To access this journal online: www.edpsciences.org 